\title{
Harmony or chaos? Beliefs and practices about conflicts among naturalized refugee children in Tanzania
}

\author{
Laurent Gabriel Ndijuye ${ }^{1,2^{*}}$ (1)
}

\author{
${ }^{*}$ Correspondence: \\ buritojr1980@yahoo.com; \\ u3002100@connect.hku.hk \\ ${ }^{1}$ College of Education, \\ The University of Dodoma, \\ Dodoma, Tanzania \\ Full list of author information \\ is available at the end of the \\ article
}

\begin{abstract}
The current study explored beliefs and practices on the main types and common causes of conflicts among naturalized refugee pre-primary children in rural Tanzania. A region with highest number of naturalized refugees in Tanzania was purposively selected. A total of 12 children were involved in the focus group discussion; nine classroom teachers, and three school principals from three pre-primary schools were individually interviewed. To gain insights on home contexts, six parents who had children in pre-primary classes were visited at their homes and interviewed on individual sessions. A number of policy and practical documents were critically analyzed. Findings revealed that the main types of conflicts among naturalized refugee children were teacher-induced and pupil-induced. Further, it was found that the main causes of conflicts among children of this group were related to scarcity of resources and social issues. These findings highlight that in order to ensure that naturalized refugee children are developing to their fullest potentials and integrated into a host Tanzanian society, deliberate efforts are much needed to understand common types and main causes of conflicts. This will help in devising appropriate strategies to develop children's constructive conflict-resolution skills.
\end{abstract}

Keywords: Pre-primary education, Tanzania, Conflict, Naturalized refugee

\section{Introduction}

Pre-primary education has increasingly become a central concern of many developing countries, particularly among those countries that have made rapid progress in universalizing primary education (Black et al. 2016; UNESCO 2007). Majority of the countries in the world, and Tanzania in particular, are grappling with the questions of how to provide skills and knowledge to enable children access and smoothly excel during primary education (Mtahabwa 2010). Such skills include cognitive, social, conflict resolution and other related skills (Ndijuye 2013; UNESCO 2000).

Though children's conflicts are common and normal part of their everyday school life (Bonache et al. 2016; Tyler 1998), however, too much of them could be problematic and may impede their ability to develop social skills (Johnson and Johnson 2000). Such destructive conflicts can take various forms, most commonly, these are subsumed

(c) The Author(s) 2020. This article is licensed under a Creative Commons Attribution 4.0 International License, which permits use, sharing, adaptation, distribution and reproduction in any medium or format, as long as you give appropriate credit to the original author(s) and the source, provide a link to the Creative Commons licence, and indicate if changes were made. The images or other third party material in this article are included in the article's Creative Commons licence, unless indicated otherwise in a credit line to the material. If material is not included in the article's Creative Commons licence and your intended use is not permitted by statutory regulation or exceeds the permitted use, you will need to obtain permission directly from the copyright holder. To view a copy of this licence, visit http://creativeco mmons.org/licenses/by/4.0/. 
in the literature under the concepts of violence and bullying, which can be both physical and/or mental in nature (Aurora 1999; Balding 1996). For example, in 1995, 58\% of children surveyed in the United Kingdom reported experiences of being bullied (Bonache et al. 2016; Tyler 1998). However, the episodes experienced are persistent and prolonged incidences of physical and/or mental violence. Indices collected by Aurora $(1994,1999)$ show that $8 \%$ to $50 \%$ of pupils in different school populations experience bullying.

In a survey of over 10,000 British children, an average of 30\% of pre-primary children reported experiences of bullying in their previous school term, and $10 \%$ on their way to, and from school (Aurora 1994; Balding 1996). Balding (1996) found that $27 \%$ of boys and $35 \%$ of girls went to school in fear of being bullied. Worldwide, an estimated 227 children and youths (age 0-19 years) die every day as a result of inter-personal violence (Garcia-Raga et al. 2017), and for each death, many more are hospitalized with injuries (UNESCO 2015; WHO 2010). Poor social skills, low academic achievement, impulsiveness, truancy and poverty are among the factors that fuel this violence (WHO 2010). For newly naturalized refugee children in Tanzania, apart from above-mentioned risks, they also face family trauma history, lack of material resources, mismatch between home language and language of instruction (Center for the Study of Forced Migration (CSFM) 2008; Kuch 2016).

\section{The contexts and civil status of naturalized refugee children in Tanzania}

For the past 50 years, Tanzania has been a safe haven for, and home to almost two million refugees who fled their countries for political or economic reasons, or because of civil war (Tanzania Ministry of Home Affairs (2014); UNHCR 2013). Most of them come from such neighboring countries such as Burundi, the Democratic Republic of Congo (formerly Zaire), Rwanda, and Somalia. The first wave of refugees, commonly known as "the first case-load", came to Tanzania in 1972 (Center for the Study of Forced Migration (CSFM) 2008; UNHCR 2013). This group was initially settled in different parts of the Kigoma region, especially in border villages along Kigoma and Kasulu towns. About two-thirds of them were later moved to Ulyankulu, Mishamo, and Katumba settlement areas in the Tabora and Katavi regions, while the rest remained in villages among the local majority, as "self-settled refugees" (Center for the Study of Forced Migration (CSFM) 2008).

By 2010, the first case-load refugee population had risen from 150,000 to about 240,000, while the self-settled population had grown from about 55,000 to 90,000 (UNHCR 2014), some 72\% of whom were born in Tanzania (Ministry of Home Affairs 2014). A distinctive feature of the self-settled refugees was that they did not receive any kind of assistance from the UNHCR, apart from meeting their educational needs. This was financed through the government of Tanzania (Ongpin 2008; UNHCR 2014). The second wave of refugees (or second case-load) came to Tanzania throughout the last decade of the twentieth century, and was settled in camps in north-western Tanzania (UNHCR 2014). However, some of them illegally moved from those refugee camps to urban areas across Tanzania and beyond (Chaulia 2003; Center for the Study of Forced Migration (CSFM) 2008).

By 2008, peace and stability had been officially restored in almost all neighboring countries that had experienced socio-political upheaval, and the second case-load was 
repatriated, or resettled in a third country (Center for the Study of Forced Migration (CSFM) 2008). The government of Tanzania and international donor agencies had to seriously consider long-term solutions for the first case-load of refugees still in settlement areas, as well as the self-settled refugees. This group was considered distinct, due to both the length of time they had been in exile in Tanzania (more than two-thirds were born in Tanzania), and their economic benefit to the country (Kuch 2016; Ongpin 2008).

In 2007, Tanzania announced its readiness to naturalize those who wanted to stay (Center for the Study of Forced Migration (CSFM) 2008). However, the 1972 self-settled refugees were not included in this program until 2010, when the government sorted out their civil status by naturalizing them (Chaulia 2003; Ministry of Home Affairs 2014; UNHCR 2012). This study focuses on children from the first case-load self-settled naturalized refugees.

\section{Perceptions and beliefs on conflicts among pre-primary children}

Conflicts in pre-primary school settings occur among and between pupils and teachers (Griffith 1996). Whereas reported incidents of inter-pupil violence appear to be high, attacks by pupils on teachers appear to be rare (Aurora 1999; Johnson and Johnson 1995). In a survey of 2500 British teachers, it was found that 1 in 200 of them had been a victim of a violent incident. The overall picture created by these findings was of teachers being ground down by persistent misbehavior rather than being beaten up (The Elton Report DES 1989). Such incidences have been attributed to lack of conflict-resolution skills (Garcia-Raga et al. 2017; Johnson and Johnson 2000), which can be better developed before and during pre-primary years.

Conflicts found in many organizations usually stem from different goals, approaches to reach the same outcome, and/or limited resources (Garcia-Raga et al. 2017). Many children and adults think of conflict as a competition that can only be judged by having a winner and a loser (Ayas et al. 2010). The problem with thinking about conflict in this way is that, it promotes win-lose behavior. Children who want to win will try to dominate others, while those children who think cannot, will try to avoid the conflict (Johnson and Johnson 2000; UNESCO 2010).

Some view conflict from negative point of view, and hence, it must be avoided at any cost (Ayas et al. 2010; Jonkman 2006). Others see conflict from a more liberal angle so that it is a phenomenon which necessitates management (Johnson and Johnson 1995; Jonkman 2006). Still, there are those who perceive conflict from a very positive point of view (Madalina 2016). Accordingly, conflicts are exciting opportunities for personal growth which should be used to their best advantages (Jonkman 2006). In academic settings, conflict is a daily incidence because of consensus of opinion concerning rules governing the school (Jonkman 2006; Madalina 2016). This seldom exists among the administrators, teachers, pupils, and parents. These parties, particularly administrators, teachers and pupils, mostly consider one another as adversaries, not as those working toward a common goal, as it is generally the case in other organizations (Madalina 2016; Mensah 2007).

In the context of developing sub-Saharan countries, studies associate conflicts in pre-primary schools with poor communication, role ambiguity, unclear expectations and regulations, unresolved prior conflicts, conflicting interests and disagreement on task and content 
issues (Adeyami 2009; Mensah 2007). Also, competition for available scarce resources, differences in values and inconsistencies among educators and learners may also bring about discord (Adeyami 2009; Jonkman 2006; Mensah 2007). However, these findings reflect the general public, and are not specifically reflective of naturalized refugee children in subSaharan contexts.

A number of research findings show that various forms of conflict occur at varying degrees and proportions in pre-primary schools (Jonkman 2006; Okotoni and Okotoni 2003). Amuseghan (2007) found that the rate of occurrence of student-authority conflicts in the United Kingdom and Canadian pre-primary schools was high. Jonkman (2006) asserts that conflicts in schools are the results of different perception, shortage of resource, and lack of communication. This is caused by inefficiency of most of the Principals to manage conflicts effectively which culminate in hike up. In his observation, he found that most of the Principals in preschools did not have knowledge on how to resolve conflicts; hence, failed to manage and resolve them properly.

\section{Perceived causes of conflicts among pre-primary children}

Dealing with conflict that occurs regularly among children can be extremely a frustrating experience (Johnson and Johnson 2000; Okotoni and Okotoni 2003; VanAcker 1993). Studies have shown that children are likely to engage in up to eight peer conflicts per hour during a typical day (Johnson and Johnson 2000; VanAcker 1993). While this may seem excessive, most conflicts tend to be short in duration (around $30 \mathrm{~s}$ ) and are often resolved by children themselves with little or no guidance from adults (Johnson and Johnson 2000).

Studies conducted in Tanzania on conflicts, conflicts management and conflict resolution mainly focused on higher education levels (Mkumbo 2002; Mosha 1994; Sambo 1997). This makes the available literature on conflict management skills at pre-primary level scanty. To our knowledge, there is no study in Tanzania that focused on naturalized refugee children as a distinctive group that needs special attention. That being the case, one remains with a partial picture about main types and causes of conflicts among naturalized refugee preprimary children. Unless such information is obtained, the future of this unique group in Tanzania will be at a high risk of having a conflict-ridden society which is unable to resolve conflicts; and consequently, rendering the overall socio-economic development problematic. Against this background, there was, therefore, an urgent need to conduct a study about main types and causes of conflicts among pre-primary school children in Tanzania. More specifically, this study aimed to answer the following research questions:

(a) What are the main types of conflicts that occur more frequently among naturalized refugee pre-primary school children in Tanzania?

(b) What are the main causes of conflicts that occur more frequently among naturalized refugee pre-primary school children?

\section{Method}

\section{Sample selection}

Given the special needs and contextual reasons for naturalized refugees in Tanzania, this study used a homogeneous purposive sampling to obtain insights and understanding 
of most common types and causes of conflicts among naturalized refugee pre-primary children. Kigoma region is home to the highest number of immigrant naturalized refugees of mixed nationalities than any other region in Tanzania, thus, purposively selected. Three pre-primary schools with largest number of children were selected, based on the assumption that the larger the school, the more the conflicts. The information about the number of pupils, frequency of cases related to escalation of conflicts, and location of a school was obtained from the local education office. This technique was also used in the selection of parents, school principals and classroom teachers.

\section{Study area and context}

In 2016, there were 1340,090 pre-primary pupils enrolled in Tanzania, out of an eligible pool of 1,535,000 pre-primary children. Among those enrolled, 17,089 were children of naturalized refugees (Ministry of Education, Science, and Technology (MEST) 2017; UNHCR 2017). In the same year, there were 8354 qualified teachers, making the teacher-pupils' ratio 1:124 compared to a 1:25 international standard ratio (Ministry of Education, Science, and Technology (MEST) 2017). However, most qualified teachers preferred to reside and work in urban areas, resulting in lower teacher-child ratios in rural pre-primary schools (Mtahabwa 2015). In 2016, the Kigoma region, home to the highest number of naturalized and camped eligible refugee pre-primary pupils $(42,156)$, had a qualified teacher-child ratio of 1:141. On average, 31.3\% of children in Tanzania were enrolled in pre-primary education, as of 2016 (UNESCO 2017). In rural Kigoma and Rukwa, where most naturalized refugees are located, only 30 and $42 \%$, respectively, of eligible students were enrolled, far below the national average of 67\% (Ministry of Education, Science, and Technology (MEST) 2017).

\section{Participants}

Each of the participating schools had a total number of about 50 enrolled pre-primary children. Among them, about 75\% were children from naturalized refugee backgrounds. A total of 12 children (4 from each school) in upper kindergarten class (K2, typically aged from 5 to 7) from each of the selected pre-primary school were selected. Three school principals ( 1 from each of the schools), 9 classroom teachers (3 from each of the preschools), and six parents (2 from each preschool) who were serving in the Parent-School Committee (PTC), were selected on the virtue of their positions. All of the selected children and parents were of Burundian origin. The selected school principals had served in the role for not less than 5 years, while classroom teachers had 3 or more years.

As indicated on Fig. 1, two third of the pre-primary school principals were more female. The teaching staff were almost entirely female ( 89 percent). Given the necessity of male-figure, this may have some implications on children's personality development. Figure 2 indicated that informants' academic qualifications ranged between basic education to bachelor degree. None had a postgraduate qualifications. Most of the informants had a teaching certificate qualification.

Parent-members of PTC together with teachers supervised daily school activities on behalf of other parents. The author assumed that they have deeper understanding of both curricular and extra-curricular levels and performance of children. Given 


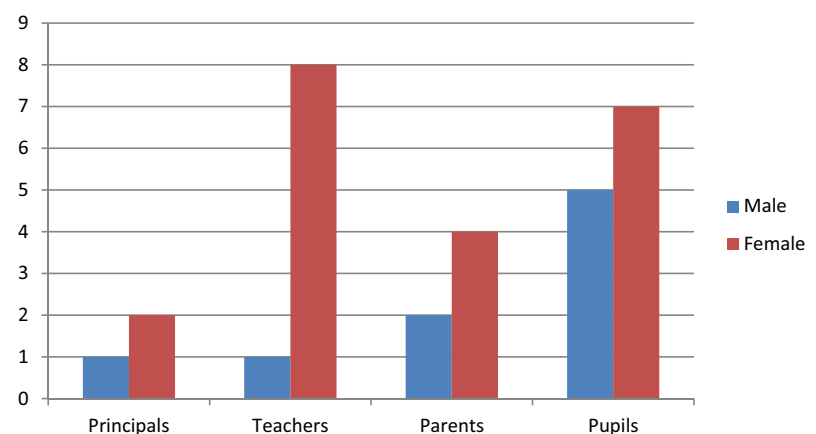

Fig. 1 Informants' distribution by gender

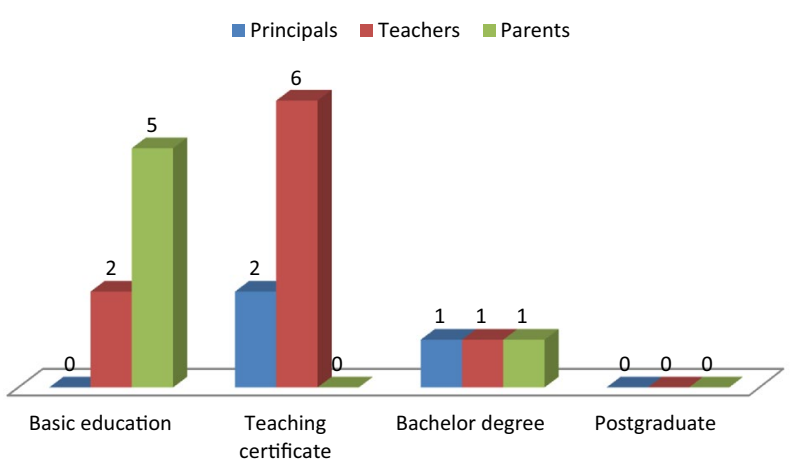

Fig. 2 Informants' educational characteristics

the objectives of the current study, the selected sample size was large enough to allow triangulation of data sources or informants (Onwuegbuzie and Leech 2007), and data collection methods (Patton 2002) hence, saturation of analyzed data (Creswell 2009). However, given the existing socio-cultural and political diversities in sub-Saharan Africa, the selected sample size was not large enough to allow generalization of findings across naturalized refugee population in this region.

\section{Data collection tools}

This study triangulated semi-structured interviews, focus group discussion (FGD), and documentary analyses in collecting the required data. Due to its flexibility and time-efficiency, semi-structured interviews were used with school principals and parents, while focus group discussion was used with teachers and children. The first two methods were used to reduce the risk of misinterpretation by informants. The two techniques provided a chance of explaining the purpose of the study and clarifying queries raised during the course of discussion (Creswell 2009). Also, these techniques permitted the establishment of rapport and co-operation between the author and the informants. This was essential in enabling informants to reveal their views in their own words (Creswell 2009; Patton 2002). The process involved face-to-face conversations where information was noted down in the field notebook complimented by a tape recorder. The responses were later compared with responses of other groups in the study. 
For this study, the targeted documents were meeting minutes, black books, transcription of school management team and board meetings. The author decided to use this method because these documents could be secured quickly and easily, and covered a wider geographical area and longer reference periods without much cost (Creswell 2009; Punch 2005). The author collected information related to types of conflicts that were dominant among pre-primary children brought to the attention of preschool boards and Parent-Teachers Committees (PTC).

\section{Ethical issues}

Ethical issues were observed by requesting an introductory letter from Tanzania's Ministry of Education, and permission from district, wards and village executive officers. Finally, the author had to consult school authorities to obtain parents' consent to include their children in the study. Confidentiality was observed and unauthorized person had no access to the collected data.

\section{Data analyses}

Data were subjected to interpretational analyses by involving systematic set of procedures to code and classify qualitative data to ensure that important constructs, themes and patterns emerge. Specifically, the raw data obtained from semi-structured interviews and FGDs were coded to obtained relevant texts, repeating ideas, themes, theoretical constructs, research concerns and theoretical narratives. It was from repeating ideas that themes and sub-themes were developed. Themes were organized into abstract ideas or theoretical constructs and later developed into theoretical narratives which were used to bridge between the concern of the author and participants' subjective experiences using their own words.

In analyzing documents, two issues guided the development of the themes: (a) how information was presented, and (b) the status of the resolution/by-law/decision. The said documents were collected and analyzed by the author. In order to maximize objectivity, communicability, transparency, and coherence techniques were deployed (Auerbach and Silverstein 2003). Specifically, the author triangulated data sources, data collection instruments, and bracketed all of his previous understandings, beliefs and assumptions during data analyses (Onwuegbuzie et al. 2012). Further, the data analyses processes were jointly done with two enumerators.

Inter-rater reliabilities Two enumerators with Bachelor of Education (B.Ed) degrees in Early Childhood Education were recruited to assist with data collection and analyses. The author coded the field notes to categorize patterns and constructs of differences in the participants' views. To ascertain inter-rater reliability, 30\% of the field notes were independently coded by the two enumerators, and inter-rater reliability calculated by the percentage of agreement among the three raters; at the end, $93 \%$ consensus was reached. 


\section{Results}

\section{Main types of conflicts among naturalized refugee pre-primary children}

The study intended to find out the main types of conflicts which were dominant among naturalized refugee pre-primary children. It was assumed that there would be some specific dominant types of conflicts among children from this group in Tanzania. Two subthemes were developed, namely teacher-induced and pupil-induced conflicts. Under each sub-theme, there were the following sub-sections: pupil-pupil; a conflict which involves one child against the other, teacher-pupil; a conflict that involve a pupil against his or her teacher, pupil-administration; a conflict which involve a pupil against school authorities such as preschool principal, and inter-class conflict-one that involves upper grade pupils against pre-primary children.

Under the sub-theme of teacher-induced conflicts, the findings revealed that the main type of conflict that occurs in pre-primary schools were as follows: 14 (40\%) statements of the teachers revealed that they experienced pupil-pupil conflicts in their respective classrooms which involved one pupil against the other. Teacher-pupil conflict was rated the second with 11 (31\%) of the informants' statements, pupil-pupil of different classes/ inter-class conflicts ranked third with 7 (20\%) statements and pupil-administration conflict was revealed in two pre-primary schools with 03 (09\%) informants' utterances. One informant said:

"Most of the naturalized refugee children had traumatic experiences, and some come from poor-mannered families where they have freedom to yell anything to any-

body. Last week when I was teaching number concept, one of them was just singing taarabu (a kind of African music popular in east African coast) in the class"

On the sub-theme of pupil-induced conflicts, findings showed that three types of conflicts were very common among naturalized preschoolers. These were pupil-pupil, teacher-pupil and inter-class. Seven (37.5\%) statements were made by informants identifying pupil-pupil as a very common and the most dominant type of conflict. Furthermore, it was revealed that four (30\%) statements rated the teacher-pupil conflicts second among naturalized refugee pre-primary school children. Another type of conflict was inter-class conflicts. The author found out that 3 (27.5\%) pupils' statements considered this type of conflict to be common in this social group. One pupil made the following statement:

"If teachers are not around, sometimes upper class boys come in our classrooms and forcibly take our chairs or porridge cups, do you think we accept? No, we either try to protect them or yell them bad names, such as 'you children of Satan".

Moreover, findings from the analyzed documents found that the pupil-induced conflicts in pre-primary school X discussed by staff meetings were those related to pupils' social issues such as theft, physical, and verbal fighting among children. In schools $\mathrm{Y}$ and $\mathrm{Z}$, the reviewed documents showed that the dominant types of conflicts were pupilpupil and very rarely teacher-pupil. It was discovered that, very few teachers were aware of the government regulation on the uses of corporal punishment. The regulation states that, corporal punishment is lawful in all public schools in mainland Tanzania under the 
National Corporal Punishment Regulations (1979) pursuant to article 60 of the National Education Act (1978).

It authorizes the Minister for Education to make regulations-to provide for and control the administration of corporal punishment in schools. The Law of the Child Act (2009) did not repeal this provision or prohibit corporal punishment in schools. Government guidelines in 2000 reduced the number of strokes from six to four, and stated that only the school principals are allowed to administer the punishment, with penalties for teachers who flout these regulations (United Republic of Tanzania 2009). From this provision, the author considered that most of the pre-primary teachers may not be aware of what this document meant in their schools.

Perhaps this is the reason teachers reported caning children without the permission of their respective school principals though it is clearly stated in the government guidelines. However, it is important to note that for teachers administering corporal punishment should not be considered as a type or cause of conflict. It is rather regarded as a common act of disciplining pupils which is acceptable and practiced in a socio-cultural context of Tanzania. However, this sample size is not large enough for generalization of findings.

\section{Main causes of conflicts among naturalized refugee pre-primary children} Teachers' views

Resource-related conflicts One of the most interesting findings revealed that, limited resources, family background, classroom space and peer pressure were the main resource-related causes of conflicts. Though it was not the only reason, poverty was found to be the most significant reason reported by (24.1\%) teachers. In this context, poverty was regarded as pupils' lack of important materials which must be provided by their respective families. Other reasons were theft (15.2\%), family background (23\%), home environment (21\%), jealous (13.2\%) and peer pressure (3.5\%). One informant reported that:

"Naturalized refugee pupils come from different family backgrounds with different economic abilities. Some pupils come into our classrooms with excellent pencils, bags and even bottles of water. Conversely, some come to school with nothing. Since they are just children, you find that have-not pupils tend to take by force or stealing the-haves' properties hence escalation of conflicts"

This finding was not surprising given that Kigoma region is one of two regions in Tanzania which has experienced a relative increase in poverty levels in the past two decades partly due to rapid population growth. Among naturalized refugees, the average family size was 9 people (National Bureau of Statistics (NBS) 2012). Existing evidences confirm the relationship between household size and poverty (Coleman, 1966; REPOA, 2016). Kafle and Jolliffe (2015) reports that in Tanzania, people living in households of seven or more are two-thirds more likely to be poor than those living in households of six or less. Further, naturalized refugee households of $6-10$ people were nearly twice as likely to be poor than non-refugee households of same number of people.

Socialization-related conflicts On this sub-theme, it was evident that teachers considered bullying by older boys of the same class or upper classes against girls or younger 
boys of their classes or lower classes (24\%), peer pressure (22\%), jealousy (20\%) and pupils' home environment such as the way parents resolve conflicts between themselves or with neighbors, contribute much to the way pupils handled conflicts in the classroom (34\%).

\section{Naturalized refugee parents' views}

On this sub-theme, it was learned that in-born aggressive behavior-there were some pupils who are naturally aggressive and violent (21\%), limited resources (18\%)-such as desks and food, peer pressure (15\%), home environment (14\%) and family background (20\%), and language barrier (12\%) were the main causes of conflicts in naturalized preprimary schools. Despite the fact that almost all teachers were Tanzanian-born and the official medium of instructions in all public pre-primary schools is Kiswahili, however, during school hours, almost all pupils spoke a vernacular language of Kirundi-their mother tongue. Language was always a source of conflicts between teachers and pupils. As one parent put it:

"Most of the teachers are fluent in Kiswahili and English, but our children can speak neither of the two languages. This always confuses our pupils and results into conflicts with their teachers"

\section{Naturalized refugee children's views}

Given the sensitivity and tender age of informants of this sub-group, open-ended, nonleading simple questions were asked. The questions focused on children's typical day, inand-out-door activities, and home environments. Findings from this sub-group could be broadly categorized into two categories: resources-related and socialization-related conflicts. More specifically, children pointed out that limited resources, home environment and family background, and bullying by elder boys were the main causes of conflicts.

Resource-related conflicts It was revealed that resources such as play materials, food, teaching and learning materials were scarce. For example, in one pre-primary school pupils were sitting on the floor because there was limited number of desks. Statements about limited resources were $12(40 \%)$ in pre-primary school X, while pupils' poverty statements were 7 (23.3\%) in pre-primary school Y and scarcity of resources and space factor statements were 2 (6.7\%) and 9 (30\%), respectively, in school Z. For example, in one school, it was revealed that the issues raised by pupils on the available space were numerous. In this regard, available space refers to all physical entities such as classroom desks, kitchen utensils and toilets. Scarcity of such resources increased a scramble for the sitting space which normally resulted in conflicts. A pupil made the following statement:

"We don't have desks, we sit on the floor, and we don't have enough toys to play with. Some pupils steal these things while others fight for these things. I think our teacher should bring us more toys to avoid fighting"

Socialization-related conflicts On this sub-theme, pupils revealed that home environment and family background is another reason for the escalation of conflicts in schools. In preschools $\mathrm{X}$ and $\mathrm{Y}, 10(37 \%)$ and $6(22.2 \%)$ statements were recorded on home 
environment and family background, respectively. Bullying was reported by 4 (14.8\%) statements were made with regard to bullying in preschool Y. Further, pupils revealed that language of instruction 7 (26\%), which was Kiswahili and sometimes English was a problem. Most of the pupils' first language was Kirundi-a vernacular mother tongue language. Since most of the teachers were from other parts of the country with extremely limited knowledge of Kirundi, communication with children was found to be a daunting task.

\section{Discussion}

\section{Main types of conflicts}

It is critically important to note that unlike the current study, the related studies that will be discussed in this study focused on general population; not naturalized refugee pre-primary children. The current study found that there were two dominant types of conflicts among naturalized refugee pre-primary children, namely teacher-induced and pupil-induced conflicts were found. They were further divided into four sub-categories namely; pupil-pupil, teacher-pupil, inter-class and administration-pupil conflicts. Experiences from both teachers and pupils revealed that pupil-pupil conflict was the most dominant and common type of conflict. This type of conflict is inevitable among pupils when one considers the current paradigm shift in Tanzania from teacher-centered to learner-centered teaching approach which emphasizes the use of more interactive and participatory teaching methods (Dembele and Lefoka 2007).

Learner-centered teaching methods allow children to work closer with their fellows than with their teachers or any other person (Ayas et al. 2010). Furthermore, the experience of both teachers and pupils revealed that, teacher-pupil conflict was also a common type of conflict. It was observed that some pupils came into conflicts with their teachers due to behavioral and family reasons. Pupils and teachers come to school with their own values and philosophies of life. Under such circumstances, conflicts between those two social groups are inevitable (Johnson and Johnson 1995).

Gender-wise, it was observed that pupil-induced conflicts were between boys and girls, but more dominant among boys themselves. Older boys tended to bully the young ones, and very rarely among girls themselves. Pupil-teacher conflicts were common between boys and teachers, and the inter-class conflicts was predominantly among boys. The dominant pupil-pupil conflicts between girls were relationship-oriented ones, while between boys were dominance-related. These findings concur with those by Shantz and Shantz (1985) who found that, the main type of conflicts between young boys was that related to possession; and between young girls was that related to relationship issues.

From the review of documents, it was revealed that, though there were no suggested types of pre-primary school children's conflicts, only elements of pupil-induced conflict were revealed. Whenever there were staff meetings or school management team (SMT) meetings, all discussions related to conflicts were centered on pupils' conflicts, purposely or unknowingly ignoring the existence of other types. This resulted in the formation of various committees to deal with children's conflicts such as Teachers' Disciplinary Committee. 
Conflicts among pre-primary children are inevitable and a very important part of the socialization process (Johnson and Johnson 1995, 2000; Shantz and Shantz 1985). This observation concurs with that of Johnson and Johnson (1995) who observed that pupilpupil conflicts are the most dominant type in schools and helps pupils to get along well with their studies. And that, pupil-induced conflicts provide pupils with opportunities for learning or improved efficiency, develop skills of communication, open up important issues or highlight problems, develop trust, and relieve anxiety, suspicion and stress (ibid).

On the other hand, Balding (1996) claims that pupil-induced conflicts are very common among pre-primary children and can be very destructive since they may lower confidence, self-esteem and security, divert energy from more important issues, destroy creativity, entrench attitudes, and cause aggressive or violent behavior which may lead to personal harm or injury to oneself or others. The findings of this study negates those by Madalina (2016) who claimed that teacher-student conflicts are the commonest types in schools followed by student-administration and student-student is the last one. However, these findings are consistent with the study by Mensah (2007) who studied conflicts in pre-primary school in Ghana and concluded that intra-student conflicts were the most dominant type of conflicts among pupils.

\section{Main causes of conflicts among naturalized refugee pre-primary children}

In the light of the findings of this study, it is obvious that circumstantial factors determined the type of conflict, which in turn, defined the reason for that conflict. Experience from pre-primary school stakeholders showed that, location of the school, its size, and the nature of the community around, were very important factors for the conflicts to occur. Johnson and Johnson (1996) establish that conflicts are situational; therefore, their causes are also subject to situational forces. The findings correspond with those by Machibula (2010) who claimed that there is no single reason for conflicts in schools since schools are mini-community where conflicts are part and parcel of everyday life; hence, unavoidable.

Scarcity of resources was named as the most common cause of conflicts among naturalized refugee children. All social groups involved in the study considered scarcity of resources notably, play materials, food and qualified teachers, to be the main reason for almost all types of conflicts. This reason has been noted by other scholars as an important cause of conflicts in schools. Deutsch (2005) found scramble for limited resources in the USA to be the most dominant cause of conflict among pre-primary children. This finding, though distant in space and time, is close to the findings in this study. However, these findings conflict with those by Higgins and Priest (1990) who concluded that the most common cause of conflict among pre-primary children is names calling.

Findings revealed that home environment was one of the main causes of conflicts among naturalized refugee children. This might be because children learn by observing and imitating. In this study, children whose parents were relatively poorer, were more involved in inter-personal conflicts than their fellows from richer families. These findings concur with those by Cummings et al. (1985) who reported that, a pre-primary child's aggression and distress reduced to base-line levels after exposure to conflict resolution between parents. Furthermore, Cummings, et al. (1991) demonstrated that, 
pre-primary children who are exposed to unresolved inter-parental conflict have significantly greater angry reactions than those who view the partially or fully resolved interparental conflicts.

Mastery and use of language of instruction was found to be one of the main causes of conflicts among naturalized refugee children. Children's mother tongue was Kirundia vernacular language, while the language of instruction was Kiswahili-a national language. Normally, teachers used Kiswahili in the classroom which, it seems, not to be properly mastered, and sometimes not understood by children. This resulted in a lot of confusion and conflicts between teachers and pupils. These findings coincide with those by Brock-Utne and Desai (2005), and Qorro (2013) who found that, it is not only English as a language of instruction that hinders effective learning; even Kiswahili is a problem among rural learners in Tanzania.

Nevertheless, both genders were involved in causing conflicts against members of their gender or the opposite one. However, there was gender difference when it came to causes of conflicts among boys and girls. Boys tended to come into conflict on issues related to physical materials and dominance tendencies like toys and other play materials, while among girls the main cause of conflict was relationship-related issues. These findings conflict with those by Ayas et al. (2010), Bonache et al. (2016) and Tizard et al. (1988), who found that boys engage more in conflicts than girls do, and the main reason for conflicts among boys and girls are the same. However, these findings concur with the ones by Shantz and Shantz (1985) who found that there was gender difference on causes of conflicts among children, whereby possessions caused more conflicts among boys and issues of friendship between young girls.

\section{Conclusion and recommendations}

Given that conflicts are inevitable in everyday life, should not be regarded as a sign of incompetence for they are legitimate aspect of human behavior useful in stimulating creative solutions to problems. Therefore, conflict may have a greater influence on teaching and learning. As such, it is in the interest of naturalized refugee pre-primary children and communities to clearly and explicitly understand most common types and causes of conflicts to design alternative strategies to develop pupils, teachers and parents' conflictresolution skills.

There is an urgent need for the Tanzania Ministry of Education to include the aspect of understanding conflicts, management and resolution skills in the curriculum for Preprimary Teachers' Training. This can be done by exposing and familiarizing studentteachers with various strategies of handling and resolving children's conflicts. And, there is a need for in-service training such as, seminars and workshops for pre-primary school principals and teachers about conflicts. This can be jointly organized by local education authorities.

Acknowledgements

The author would like to thank parents, school principals, teachers and children involved in this study. Mr. Nemes Danstan, Emmanuel Penneza and Paschal Russambi who at different points worked as research assistants. 


\section{Authors' information}

LGN is a lecturer at the University of Dodoma-Tanzania with a passion for research in early years' education. He has PhD in Early Childhood Education from the University of Hong Kong. His areas of research interests include Early Childhood Care and Education (ECCE), Early Numeracy and Literacy Acquisition Skills (ENLAS), Refugee Education (RE), Immigrant and Minority Education (IME), Equity and Social Justice in Education (ESJE).

\section{Funding}

The author would like to gratefully acknowledge funding support of Patrice L. Engle Dissertation Grant offered by the Society of Research in Child Development (SRCD) in 2014.

\section{Availability of data and materials}

Given that the current study used predominantly a qualitative design, data and materials are available upon request.

\section{Competing interests}

The author declares no competing interests.

\section{Author details}

${ }^{1}$ College of Education, The University of Dodoma, Dodoma, Tanzania. ${ }^{2}$ Present Address: 15 Block J, Nkuhungu West, P.O Box 523, Dodoma, Tanzania.

Received: 22 March 2018 Accepted: 24 December 2019

Published online: 13 January 2020

\section{References}

Adeyami, T. O. (2009). Principals' management of conflicts in public schools in Indo State, Nigeria: A critical Survey. Educational Research and Reviews, 4(9), 418-426.

Amuseghan, S. A. (2007). Peace and conflict studies: An introductory text. Akure: Stebak Books and Publishers.

Auerbach, C. F., \& Silverstein, L. B. (2003). Qualitative data: an introduction to coding and analysis. New York: New York University Press.

Aurora, T. (1994). Levels of bullying measured by British schools using the $=$ life in schools' checklist: A case for benchmarking? Pastoral Care in Education, 1(1), 17-22.

Aurora, T. (1999). New levels of bullying measured by British schools using the life in school'checklist: A case for benchmarking?. Pastoral Care in Education, 6(1), 37-42.

Ayas, T., Deniz, M., Kagan, M., \& Kenç, F. M. (2010). An investigation of conflict resolution strategies of adolescents. Procedia Social and Behavioral Sciences, 2(2), 3545-3551.

Balding, J. (1996). The young people that are afraid of going to school. Education and Health, 14(1), 5-13.

Black, M. M., Walker, S. P., Fernald, L. H., Andersen, C. T., Digirolamo, A. M., Lu, C., et al. (2016). Early childhood development coming of age: science through the life course. Lancet, 1, 1-14.

Bonache, H., Ramirez-Santana, G., \& Gonzalez-Mendez, R. (2016). Conflict resolution styles and teen dating violence International Journal of Clinical and Health Psychology, 16, 276-286.

Brock-Utne, B., \& Desai, Z. (2005). Expressing oneself through writing-A comparative study of learners-writing skills in Tanzania and South Africa. In B. Brock-Utne, Z. Desai, \& M. Qorro (Eds.), LOITASA research in progress (pp. 224-256). KAD Associates: Dar es Salaam.

Center for the Study of Forced Migration (CSFM). (2008). Citizenship and Forced Migration in the Great Lakes Region. Working Paper No. 1. Dar es Salaam: University of Dar es Salaam press.

Chaulia, S. S. (2003). The politics of refugee hosting in Tanzania: From open door to unsustainability, insecurity and receding receptivity. Journal of Refugee Studies, 16(2), 147-166.

Coleman, J. S. (1966). Equality of Educational Opportunity. Washington, DC: U.S. Dept. of Health, Education, and Welfare, Office of Education.

Creswell, J. W. (2009). Research design: A qualitative, quantitative and mixed method approaches (3rd ed.). Thousand Oaks: Sage Publishers.

Cummings, E. M., lannotti, R., \& Zahn-Waxler, C. (1985). The in-fluence of conflict between adults on the emotions and aggression of young children. Developmental Psychology, 21, 495-507.

Dembele, M., \& Lefoka, P. (2007). Pedagogical renewal for quality universal primary education: Overview of trends in subSaharan Africa. International Review of Education, 53, 531-553.

Deutsch, M. (2005). The resolution of conflict. New Haven: Yale University Press.

Garcia-Raga, L., Graub, R., \& Lopez-Martin, R. (2017). Mediation as a process for the management of conflict and the improvement of coexistence in educational centres. A study based on the perceptions of secondary school students. Procedia Social and Behavioral Sciences, 237, 465-470.

Griffith, I. (1996). Research paper on the peer mediation project. Edinburgh: The Scottish Council for Research in Education. Higgins, A., \& Priest, S. (1990). Resolving conflicts between young people. Educational Psychology in Practice., 6(2), 60-64. Johnson, D. W., \& Johnson, R. T. (1995). Reducing school violence through conflict resolution. Virginia Association for Curriculum and School Development, 16(22), 459-506.

Johnson, D. W., \& Johnson, R. T. (1996). Conflict resolution and peer mediation programs in elementary and secondary schools: A review of the research. Review of Educational Research, 66(4), 459-506.

Johnson, D. W., \& Johnson, R. T. (2000). Joining together: Group theory and group skills (6th ed.). Prentice-Hall: Englewood Cliffs.

Jonkman, N. (2006). Management of conflicts by principals in selected soshanguve secondary schools, Department of Education Studies: Tisane University of Technology. 
Kafle, K. \& Jolliffe, D. (2015). Effects of asset ownership on child health indicators and educational performance in Tanzania. Selected paper prepared for presentation for the agricultural and applied economics association (WAEA) Annual Meeting, San Francisco, CA, July 26-28.

Kuch, A. (2016). Naturalization of Burundian refugees in Tanzania: The debates on local integration and the meaning of citizenship revisited. Journal of Refugee Studies, 30(3), 468-487.

Machibula, J. M. (2010). Conflict management and resolution skills among secondary school students. The case of Nzega district - Tabora region. Tanzania: The University of Dodoma (unpublished).

Madalina, O. (2016). Conflict management, a new challenge. Procedia Economics and Finance, 39, 807-814.

Mensah, M.O. (2007). Conflict in Pre and Primary Schools and its Effects on Teaching and Learning: a case study of Ejisujuaben District Ashanti region, Unpublished M.A Education Dissertation Accra University.

Ministry of Education, Science, and Technology (MEST). (2017). Basic education statistics in Tanzania. Dar es Salaam: Government press.

Ministry of Home Affairs. (2014). Refugees Status and Statistics. Retrieved from: http://www.moha.go.tz/sites/default/files/ tanzania\%20refugee\%20policy\%202003.pdf.

Mkumbo, K. K. (2002). Management and Resolutions of Violent Intra-Students Conflicts in Institutions of Higher Learning in Tanzania. Unpublished Master Dissertation, University of Dar es salaam.

Mosha, H. J. (1994). Conflicts management and organizations health in universities: Lesson from Tanzania. Oslo: Norwegian University Press.

Mtahabwa, L. (2010). Provision of Pre-primary Education as a Basic Right in Tanzania: reflections from policy documents. Contemporary Issues in Early Childhood, 11(4), 353-364. Retrieved from: http://journals.sagepub.com.eproxy1.lib.hku. hk/doi/pdf/10.2304/ciec.2010.11.4.353.

Mtahabwa, L. (2015). Aligning pre-primary teacher education programmes to policy and curricula in Tanzania. Journal of Education, Humanities \& Sciences, 4(2), 36-53.

National Bureau of Statistics (NBS). (2012). Tanzania Basic Demographic and Socio-economic Profile. Dar Es Salaam: Government press.

Ndijuye, L.G. (2013). Strategies to Develop Conflict Resolution Skills among Preschoolers: Observations from Rural and Urban Districts in Tanzania. Unpublished M.A. Dissertation. The University of Dodoma - Tanzania.

Okotoni, O., \& Okotoni, A. (2003). Conflict management in secondary schools in Osun state. Ife: Obafemi Awolowo University Press.

Ongpin, P. (2008). Refugees in Tanzania-asset or burden? Journal of Development and Social Transformation, 5, 13-23.

Onwuegbuzie, A. J., \& Leech, N. L. (2007). A call for qualitative power analyses. Quality \& Quantity, 41, 105-121.

Onwuegbuzie, A. J., Leech, N. L., \& Collins, K. M. T. (2012). Qualitative analysis techniques for the review of literature. The Qualitative Report, 17(56), 1-28.

Patton, M. Q. (2002). Qualitative research and evaluation methods (3rd ed.). California: Sage Publications.

Punch, K. F. (2005). Introduction to social research: Qualitative and quantitative approaches. London: Sage Publications.

Qorro, M. A. S. (2013). Language of instruction in Tanzania: Why are research findings not heeded? International Review of Education, 59(1), 29-45.

Sambo, W.L. (1997). Determinants of Frequent Students Crisis in Education Institutions of Higher Learning in Tanzania, Unpublished M.A. Dissertation, University of Dar es salaam Press.

Shantz, C. U. \& Shantz, D. W. (1985). Conflict between children: Social-cognitive and sociometric correlates. In: Berkowitz L. (Ed.) Peer Conflict and Psychological Growth: New Directions for Child Development, No. 29, San Francisco, Jossey-Bass.

Tizard, B. P., Burke, J., Farquhar, C., \& Plewis, I. (1988). Young children at school in the inner city. Hove: Lawrence Erlbaum.

Tyler, K. (1998). A comparison of the no blame approach to bullying and the ecosystemic approach to changing problem behaviors in schools. Pastoral Care in Education, 16, 26-33.

UNESCO. (2000). Dakar Framework for Action, World Education Conference. Unpublished UNESCO Dakar report.

UNESCO. (2007). EFA Global Monitoring Report. Strong foundations: Early childhood care and education. Paris: UNESCO Publishing.

UNESCO. (2010). EFA Global Monitoring Report:Reaching the Marginalized. Paris: UNESCO Publishing. Retrieved from http:// unesdoc.unesco.org/images/0014/001477/1567794e.pdf.

UNESCO. (2015). EFA Global Monitoring Report-Education for All 2000-2015: Achievements and Challenges. Paris: UNESCO publishing. Retrieved from: http://unesdoc.unesco.org/images/0023/002322/232205e.pdf.

UNESCO. (2017). EFA Global Monitoring Report. Accountability in education: Meeting Our Commitments. Paris: UNESCO publishing. Retrieved from: http://unesdoc.unesco.org/images/0025/002593/259338e.pdf.

UNHCR. (2012). Global Trend Report: Displacement-The New 21st Century Challenge. New York: UNHCR publishing. Retrieved from: http://www.unhcr.org/globaltrendsjune2013/UNHCR\%20GLOBAL\%20TRENDS\%202012_V08_web. pdf.

UNHCR. (2013). The Labour Market Integration of Resettled Refugees. Policy Development and Evaluation Services. Geneva. Retrieved from: http://www.unhcr.org/5273a9e89.pdf.

UNHCR. (2014). Global Trend Report: War's Human Cost. New York: UNHCR publishing. Retrieved from: https://s3.amazo naws.com/unhcrsharedmedia/2013-globaltrends/Global_Trends_report_2013_V07_web_embargo_2014-06-20. pdf.

UNHCR. (2017). Global trends report: forced displacement. New York: UNHCR. http://www.unhcr.org/576408cd7.pdf.

United Republic of Tanzania. (2009). Law of the Child Act. Dares Salaam: Government Press.

Van Acker, R. (1993). Dealing with conflict and aggression in the classroom: What skills do teachers need? Teacher Education and Special Education, 16(1), 23-33.

WHO. (2010). Mental and social aspects of health of populations exposed to extreme stressors. Unpublished WHO report. https://www.who.int.

\section{Publisher's Note}

Springer Nature remains neutral with regard to jurisdictional claims in published maps and institutional affiliations. 